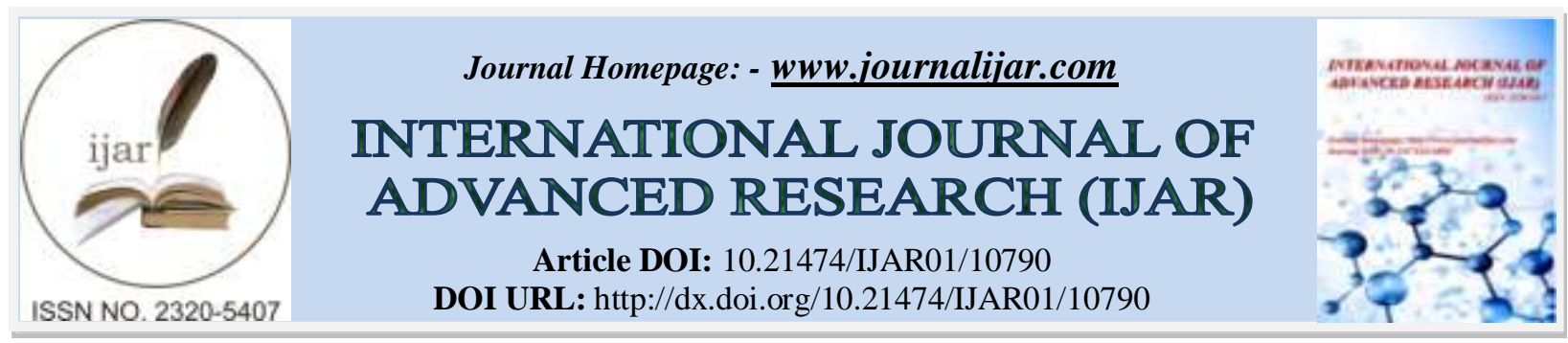

RESEARCH ARTICLE

\title{
BEHAVIORAL INTENTION TO THE USE OF FINTECH AND GOVERNMENT SUPPORT IN DEVELOPING THE THEORY OF TECHNOLOGY ACCEPTANCE MODEL
}

\author{
Henry Andreas L. Tobing S.I.P ${ }^{1}$ and Ir. Boni Benyamino L. Tobing M.MP \\ 1. Research Scholar, Department of Economics, ABFI Institute Perbanas, DKI Jakarta. \\ 2. Lecturer, Department of Economics, ABFI Institute Perbanas, DKI Jakarta.
}

\section{Manuscript Info}

.

Manuscript History

Received: 10 February 2020

Final Accepted: 12 March 2020

Published: April 2020

\section{Abstract}

Financial technology is still an interesting topic in public talks and discussions among academics. Financial technology is a combination of business innovation and technology become the solution for previous financial services. To study influential variabel to see people acceptance in using fintech by Technology Acceptance Model. On the basis of the results, it was recommended to using the development $f$ the Technology Acceptance Model because the variabel have been developed that obatained the result of elaboration and futher analysis.

Copy Right, IJAR, 2020,. All rights reserved.

\section{Introduction:-}

Financial technology is still an interesting topic in public talks and discussions among academics. Fintech began to develop in recent years and is still a debate for users in Jakarta and other big cities because there is no standard regulation and supervision from the government in Indonesia. Financial technology / FinTech is a combination of financial services with technology that eventually changes the form of business from conventional to moderate, where in the payment process is done face-to-face and carry a sum of cash, now can make long-distance transactions by making payments that can be done in a matter of only seconds (Indonesia, 2019). The understanding of fintech is based on the Central Bank of Indonesia, other studies can open up insights and knowledge about fintech itself and its development in various countries that have implemented it.

Financial technology (FinTech) is a combination of business innovation and technology to become the solution for previous financial services (Jin et al., 2019). Products from fintech itself are e-wallet, peer-to-peer lending, crowdfunding, and technology insurance. These products are choices that are calculated for consumers and businesses. Fintech has made digital economic developments in India, China, and Britain. The use of fintech in Malaysia is different, many have not used or are aware of the digital economy that exists in that country. FinTech's history began in the 1950s where credit card service users aimed to begin reducing cash-carrying. The development of fintech itself started from the emergence of ATMs (Automated Teller Machines) used and these services to reduce tellers and branches for cash withdrawals to the online banking system in the 1990s. Financial technology sustainability is digitalization in the 21st century via mobile wallets, payment apps, Robo advisors for wealth and financial planning, crowdfunding platforms for alternative financing opportunities.

Other research views that Fintech is a digital technology with unity, big data, and profitable investments are very important and can be used widely in the financial sector (Gabor \& Brooks, 2017). financial technology, also known as "FinTech", is an innovation in the field of financial services that appears with the latest technology, or what is called cellphone-based payment, is a type of service that exists in China, Korea and the UK (Huei et al., 2018). Data 
obtained from the American consulting firm Accenture, from 2010 to 2016, global Fintech investment increased from 12 billion dollars to 153 billion dollars, an increase of 12x. not only that the nominal of fintech companies has increased from existing 800 companies in April 2015 to 2000 fintech companies at the end of December 2016 with fintech investments able to get 23.2 billion dollars in 2016, up $21.5 \%$ from the previous year.

Fintech is a competitor of the national banking industry in the credit sector. Research conducted by PricewaterhouseCoopers Indonesia explains that banks in Indonesia are making every effort to offset the new changes that are starting to occur, where only $8 \%$ of respondents from all informants claim that their banks have the same strategy as the strategy in 2017 ago. Although in 2018 it will improve compared to last year, risks associated with technology are still one of the main concerns of bankers in the banking industry in Indonesia. These concerns explain that the operation of fintech in Indonesia has had an impact on the banking industry (PwC, 2018). The transition to mobile and internet platforms is not new, but the speed of change in Indonesia is very significant. Just three years ago, $75 \%$ of bankers estimated that more than half of the transactions were done through conventional branch offices - now this number has fallen to $34 \%$, while the trend of transactions on the digital line has risen to $35 \%$. The transition has also become a stepping stone for fintech companies that already rely on and prioritize the ease of the process of only using mobile phones and the internet.

Fintech business phenomenon in research in several countries and the results can explain the acceptance of fintech varies. In the development of investment in fintech, an explanation of the most important elements of fintech is a mobile-based payment, fintech products, and fintech polemic in a country. Regulation is often a negative connotation, but in the fintech community, it is acceptable where regulations provide the support needed by financial institutions and the public to feel comfortable operating in this space. Regulators or often praised by being the main facilitator in the UK's position as the leading jurisdiction for the fintech business to establish the business. The FCA's regulatory sandbox, the largest and arguably the most successful sandbox in the UK, has provided the ability for fintech businesses to test their products in a controlled environment, with the FCA continually learning from each cohort and using this to guide advancements in regulation.

This has led to huge growth in regulator tech space, a sub-sector of fintech that is now often seen as a sector with its rights, providing more effective and efficient solutions for developing regulations. Increased regulation is a factor in driving fintech to the UK which in turn creates more use of fintech inefficient ways to overcome regulation so that the chicken and egg scenario ensues(Walker, 2019)

Once the importance of these regulations, to make fintech acceptance in a country is very high. Regulations that support companies and users (the community) are a win-win solution but are by large corridors set by the government. Support from the government will be seen in the application of the latest technology to its citizens in the form of a regulation.

Based on the introduction, it is known that there is a phenomenon of fintech business in the world including Indonesia. The author also adds how fintech in Indonesia, especially fintech loans has become a concern in recent years. The phenomenon of fintech business in several countries, as well as explanations in several studies and existing sources, have a focus of explanation on the phenomenon of fintech. In the development of investment for fintech, an explanation of the most important elements of fintech is a mobile-based payment, fintech products, and polemic fintech in a country. Based on this, it is necessary to study influential variables to see people's acceptance in using the currently booming fintech in Indonesia and tge world by using the development of the Technology Acceptance Model (TAM). The results of this study can provide information in the form of the conceptual development of the Technology Acceptance Model (TAM) and its application to Fintech so that later it can be used as consideration in further research. This research can become an added concept in knowing the character of each prospective fintech user in an area (Research Area) so that it can become an input for Fintech companies in deciding their business development.

\section{Literature review or theoritical background: Intention to Use:}

Intention to use is when someone already has a view and assessment of fintech. It is also planned to use fintech and will recommend it if it has received the benefits offered by the fintech. This is explained that if the views and evaluations of fintech are positive then the community or someone will use fintech and recommend it, and vice versa the views and ratings of that person on fintech are negative or bad (Gomber et al., 2018). 


\section{Behaviour Intention :}

Behavior intention is someone's subjective view of using fintech technology. In the ground theory, Technology acceptance model (TAM) explains that there is a positive influence between one's subjective views and one's intention to use fintech itself (Saji \& Paul, 2018). This can explain if someone's subjective view of fintech is positive, which of course will produce a desire to use fintech in the future if they have the opportunity.

\section{Perceived Risk:}

Perceived risk is the risk that everyone will accept when he has made a decision (Huei et al., 2018). In the current information technology, perceived risk can explain that the use of fintech is still very risky because the personal information held by the users can be obtained by outsiders without permission from the owner of the personal data. According to Lee, explaining that the higher the level of risk to be accepted by someone, the more reluctant that person to use existing technology in this condition is the use of fintech (Lee, 2009).

\section{Perceived Cost:}

Perceived costs are costs that someone will incur when adopting the technology. Costs that will be incurred by someone will be the main concern for someone to decide on the use of the technology (Saji \& Paul, 2018). Can be said the number of additional costs that will be charged to the public or someone as a potential user to use fintech products and services will largely determine his decision

\section{Perceived Ease of Use:}

Perceived ease of use can be defined as how easy is the effort needed to use a new system or technology. Users think that fintech can have a direct impact on the sustainability of its business. Previous research also explained that there was a positive effect on the ease of use with one's attitude in using fintech (Gabor \& Brooks, 2017). The ease of use will increase one's taste in using it

\section{Perceived Usefullness:}

Perceived usefulness is how useful technology is for someone so that someone will easily adopt it. Perceived usefulness for a customer or prospective customer will be a significant influence in determining in deciding whether or not to use the fintech. Research conducted in Taiwan explains that perceived usefulness is strongly related to a person's behavioral intention to use this fintech technology (Saji \& Paul, 2018).

\section{Government Support:}

Government support has the greatest influence on someone in deciding whether to use fintech or not (Model, 2019). That is because the government determines the regulations of the products or services provided by fintech. One study by Kiwanuka et al explained that government support for fintech services and products has a positive effect on someone to use it (Kiwanuka, 2015). Marakarkandy et al. found that government support in terms of regulation and supervision is crucial for someone to want to use it in their daily lives (Markarkandy, 2017).

\section{Research objective and methodology:}

This paper targets the purpose of the conceptual model for the technology acceptance model in the financial technology sector. The paradigm of the paper used is positivism which sees that previous research is true and scientific.(Wahyuni, 2019)

The approach that is tried to be built in this paper is the historical approach to research, so this research is based on the collection of previous research and the aim to review previous research to offer a basic model of technology acceptance models (TAM) that have developed behind this. This research model offering is based on research that has been elaborated to be carried out in subsequent studies with new cases. Data analysis uses domains and taxonomy. Domain analysis means that the paper elaborates on the general picture with two starting points, namely behavior intention and Intention to use. The taxonomy means looking at previous studies the structure of variables in it to be analyzed. So, in the end, the latest variables and hypotheses will be displayed in the latest research models and formed hypotheses.

\section{Discusion:-}

In this discussion can discuss Technology Acceptance Model (TAM) along with tables from previous studies related to research to be carried out along with indicators or statements 
Previous Research:

\begin{tabular}{|c|c|c|}
\hline Variable & Indicator / Statement & Reference \\
\hline Perceived Risk & $\begin{array}{l}\text { 1.1 Fintech Loan Services are still very } \\
\text { risky } \\
\text { 1.2 The use of Fintech can make personal } \\
\text { data revealed }\end{array}$ & $\begin{array}{l}\text { (Marakarkandy, 2017) } \\
\text { (Grabner, 2008) }\end{array}$ \\
\hline Perceived Cost & $\begin{array}{l}\text { 2.1 The use of Fintech technology is } \\
\text { more expensive } \\
\text { 2.2 The maximum cost is a reference for } \\
\text { using Fintech technology }\end{array}$ & (Lowe \& Alpert, 2007) \\
\hline Perceived Ease to Use & $\begin{array}{l}\text { 3.1 Fintech can easily be found } \\
\text { 3.2 The use of the Fintech application } \\
\text { can be easily learned } \\
\text { 3.3 Fintech makes prospective creditors } \\
\text { have a choice in the credit application } \\
\text { process }\end{array}$ & $\begin{array}{l}\text { (Jeong, 2013) } \\
\text { (Deepa, 2018) } \\
(\mathrm{Wu}, 2005)\end{array}$ \\
\hline Perceived Usefullness & $\begin{array}{l}\text { 4.1 Fintech is able to provide loans } \\
\text { quickly } \\
\text { 4.2 Fintech provides Improvement of the } \\
\text { credit application process } \\
\text { 4.3 Fintech is able to answer the needs of } \\
\text { prospective creditors }\end{array}$ & $\begin{array}{l}\text { (Szajna, 1994) } \\
\text { (Deepa, 2018) } \\
\text { (Lockett, } 1997 \text { ) }\end{array}$ \\
\hline Government Support & $\begin{array}{l}\text { 5.1 The government has clear regulations } \\
\text { regarding the operations of the Fintech } \\
\text { company } \\
\text { 5.2 Government support to prospective } \\
\text { users of Fintech }\end{array}$ & (Marakarkandy, 2017) \\
\hline Behavior Intention & $\begin{array}{l}\text { 6.1 If you have access to Fintech intend } \\
\text { to use it } \\
\text { 6.2 If I need credit I will study the fintech } \\
\text { application } \\
\text { 6.3 Fintech is a great idea in developing a } \\
\text { business }\end{array}$ & $\begin{array}{l}\text { (Szajna, 1994) } \\
\text { (Deepa, 2018) } \\
\text { (Grabner, 2008) }\end{array}$ \\
\hline Intention to Use & $\begin{array}{l}\text { 7.1 I will use Fintech in the near future } \\
\text { 7.2 I would recommend Fintech to my } \\
\text { colleagues }\end{array}$ & (Marakarkandy, 2017) \\
\hline
\end{tabular}

After seeing the existing indicators and variables from previous studies, a conceptual framework was proposed (see Figure 2.1) for future empirical research. The development of behavioral intention which consists of variables that are routinely used plus support from the government as well as hypotheses regarding the connection of the five variables to one's behavior intention in accepting the application of technology (TAM) 


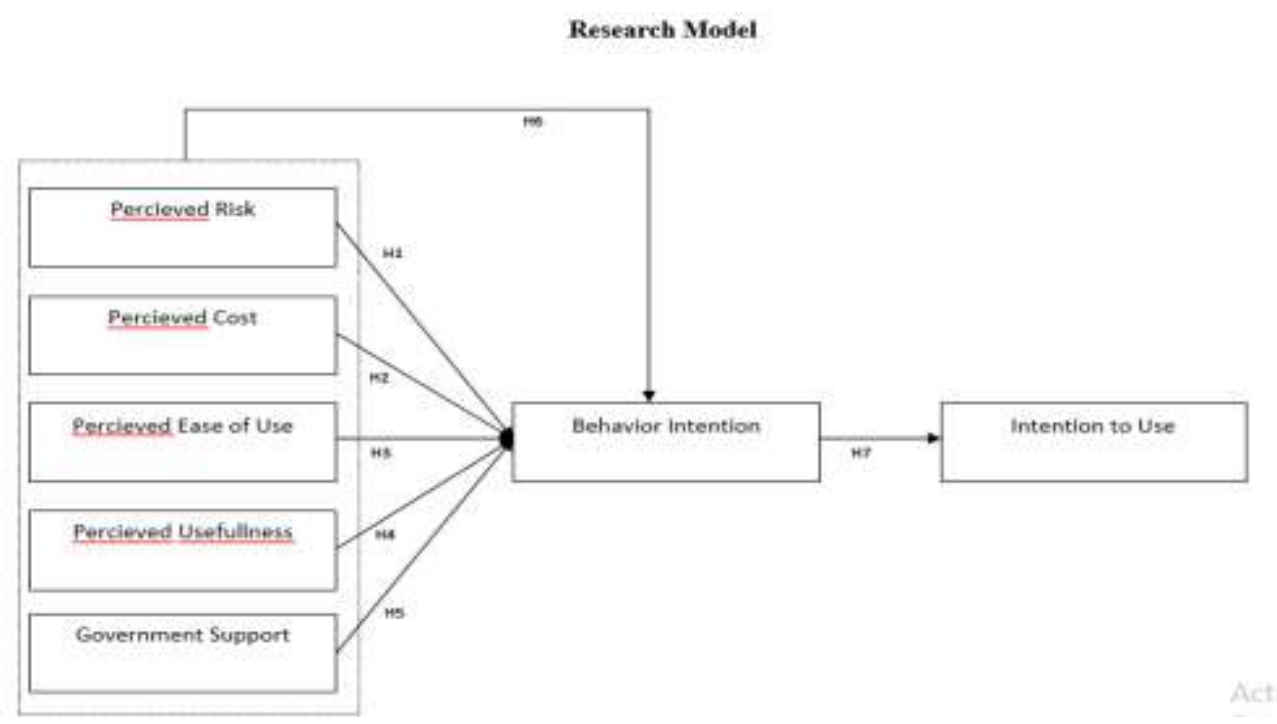

Figure 2.1:-

The following is a research model that has been elaborated from behavioral intention and intention to use and looks at previous research in structuring the structure for analysis. We can also do this with hypotheses that have emerged from the research models listed above. We can form seven hypotheses with this research model, namely:

Hypothesis $1 \quad$ :There is a negative influence between Perceived Risk and behavior intention

Hypothesis 2 :There is a negative influence between Perceived Cost and behavior intention

Hypothesis 3 :There is a positive influence between Perceived Ease to Use with behavior intention

Hypothesis 4 :There is a positive influence between perceived usefulness and behavior intention

Hypothesis 5 :There is a positive influence between government support and behavior intention

Hypothesis 6 :There is a positive influence of Perceived risk, Perceived Cost, Perceived usefulness, and Perceive ease to use (TAM), Government Support on behavior Intention to Use financial technology.

Hypothesis 7 : There is a positive influence between behavioral intention and intention to use

\section{Conclusion:-}

The purpose of this paper is to explain that the technology acceptance model is very much based on behavioral intention. But the variables in it are still developing. The majority of previous research has focused on perceived risk, perceived costs, perceived benefits, and perceived ease of use. The latest variable from the development of TAM itself is Government support which is an important part of making someone want to use certain technological innovations in this case regarding financial technology. Another new thing is how to see the effects of perceived risk, perceived costs, perceived benefits, and Perceive easy to use (TAM), Government Support for the intention to use financial technology. It is hoped that later it can become the basis of researchers with research models in the discussion of further research

\section{Reference:-}

1. Gabor, D., \& Brooks, S. (2017). The digital revolution in financial inclusion : international development in the fintech era. New Political Economy, 0(6), 1-14. https://doi.org/10.1080/13563467.2017.1259298

2. Gomber, P., Kauffman, R. J., Parker, C., \& Weber, B. W. (2018). On the Fintech Revolution: Interpreting the Forces of Innovation, Disruption, and Transformation in Financial Services. Journal of Management Information Systems, 35(1). https://doi.org/10.1080/07421222.2018.1440766

3. Grabner-Kr Uter, S.; Faullant, R. Consumer Acceptance of Internet Banking: The Influence of Internet Trust.Int. J. Bank Mark. 2008, 26, 483-504.

4. Huei, C. T., Cheng, L. S., Seong, L. C., Khin, A. A., Ling, R., \& Bin, L. (2018). Preliminary Study on Consumer Attitude towards FinTech Products and Services in Malaysia. June.

5. Indonesia, B. (2019). Financial Technology. Www.Bi.Go.Id. https://www.bi.go.id/id/edukasi-perlindungankonsumen/edukasi/produk-dan-jasa-sp/fintech/Pages/default.aspx

6. Jeong BK, Yoon TE. An empirical investigation on consumer acceptance of mobile banking services. Bus Manage Res. 2013; 2(1):31-40. 
7. Jin, C. C., Tunku, U., Rahman, A., Seong, L. C., Tunku, U., Rahman, A., Khin, A. A., Tunku, U., Rahman, A., \& Motivation, T. (2019). Factors Affecting the Consumer Acceptance towards Fintech Products and Services in Malaysia. December 2018. https://doi.org/10.18488/journal.1.2019.91.59.65

8. Kiwanuka, A. Acceptance Process: The Missing Link between Utaut and Diffusion of Innovation Theory. J. Theor. Appl. Inf. Technol. 2015, 46, 11-16.

9. Lowe, B., \& Alpert, F. (2007). Measuring reference price perceptions for new product categories: Which measure is. April. https://doi.org/10.1108/10610420710740007

10. Lee KC, Chung N. Understanding factors affecting trust in and satisfaction with mobile banking in Korea: A modified Delone and Mclean's model perspective. Interact Comput. 2009; 21(5-6):385-392

11. PwC. (2018). 2018 Indonesia Banking Survey Technology shift in Indonesia is underway. February. https://www.pwc.com/id/en/publications/assets/financialservices/2018-indonesia-banking-survey.pdf

12. Saji, T. G., \& Paul, D. (2018). Behavioural Intention to the Use of Mobile Banking in Kerala : An Application of Extended Classical Technology Acceptance Model. 1-9. https://doi.org/10.1177/0972622518792802

13. Wahyuni, sari. (2019). Qualitative research method Theory and practice (3rd Editio). Salemba Empat.

14. Walker, M. (2019). UK: Doom and Gloom or Fintech Boom? Https://Thefintechtimes.Com. https://thefintechtimes.com/fintech-boom/

15. Szajna B. Software evaluation and choice: Predictive validation of the technology acceptance instrument. MIS Q. 1994;18(3):319-3218

16. Walker, M. (2019). UK: Doom and Gloom or Fintech Boom? Https://Thefintechtimes.Com. https://thefintechtimes.com/fintech-boom

17. Wu JH, Wang SC. What drives mobile commerce? An empirical evaluation of the revised technology acceptance model. Inf Manage. 2005; 42(5):719-729.

18. Marakarkandy, B.; Yajnik, N.; Dasgupta, C. Enabling Internet Banking Adoption: An Empirical Examination with an Augmented Technology Acceptance Model (Tam). J. Enterp. Inf. Manag. 2017, 30, 263-294. 